\title{
PERANCANGAN DESAIN PENGALAMAN TURISTIK MELALUI ECOTOURISM RUMAH ADAT BALI KUNO DI DESA MANGESTA KECAMATAN PENEBEL KABUPATEN TABANAN PROPINSI BALI
}

\author{
R.M. Pramutomo \\ I Nyoman Murtana \\ Soemaryatmi \\ Fakultas Seni Pertunjukan dan Program Pascasarjana \\ Institut Seni Indonesia - Surakarta \\ Email: rmpram@yahoo.com.sg
}

\begin{abstract}
This article based on the research's result of empowering the traditional architecture in Bali called Bale Mundhak. The Bale Mundhak originally is a traditional house which is potentially related to its activities inside the building and surround it. Several problems had known and it has been indicated by some proposed research. Some of them presented through this article as a result of the first year target of the research proposition. Through this article the propose will be answered identification of Bale Mundhak's function as a traditional house in Mangesta village, district Penebel of Tabanan region in Bali. In other side this article will also strives identification several social and cultural activities inherence to the traditional function of Bale Mundhak as a rites location. And the last proposition this article will also examines the Bale Mundhak and its function related to the special arts activities in dance and gamelan music. All the propose research will expose a creative industry based on tourist village by empowering Bale Mundhak as a traditional house in Mangesta village and its arts activities which is supporting human resources surround the village based on ecotourism inclusively
\end{abstract}

Keywords: Bale Mundhak, function, arts activities, and ecotourism.

\begin{abstract}
ABSTRAK
Artikel ini didasarkan pada hasil penelitian tentang pemberdayaan arsitektur tradisional di Bali disebut Bale Mundhak. Bale Mundhak awalnya adalah rumah tradisional yang potensial yang berhubungan dengan kegiatan dalam bangunan dan sekitarnya. Beberapa persoalan telah diketahui dan telah ditunjukkan oleh beberapa peneliti melalui tujuan penelitiannya. Beberapa dari yang mereka sajikan melalui artikel ini sebagai merupakan bagian dari tahun pertama penelitian. Melalui artikel ini indentifikasi mengenai tujuan dan fungsi dari Bale Mundhak sebagai rumah tradisional di Desa Mangesta, Kecamatan Penebel dari Kabupaten Tabanan- Bali. Di sisi lain artikel ini juga akan berusaha identifikasi beberapa kegiatan sosial dan budaya dari sifatnya dan fungsi secara tradisional dari Bale Mundhak sebagai lokasi upacara. Terakhir pada tujuan artikel ini juga membahas Bale Mundhak dan fungsi utamnya, khususnya aktivitas kesenian dalam tari dan musik gamelan. Seluruh tujuan penelitian akan mengekspos berdasarkan desa wisata dengan memberdayakan Bale Mundhak sebagai rumah tradisional di desa Mangesta dan arts kegiatan yang mendukung sumber daya manusia mengelilingi desa berdasarkan ekowisata inklusif
\end{abstract}

Kata kunci: Bale Mundhak, Fungsi, Kegiatan Seni, dan Ekowisata . 


\section{PENGANTAR}

Penelitian ini muncul dari permasalahan bahwa masyarakat dan stakeholder kepariwisataan di Desa Mengesta perlu diberdayakan karena mereka belum memanfaatkan potensi diri, daya investasi, teknologi, pengetahuan, lingkungan, dan keterampilan menjadi tantangan serta peluang ke depan. Itu sebabnya studi ini menjadi sangat penting untuk dilaksanakan. Bagaimana mendesain model pemberdayaan dan stakeholder wisata di desa tersebut agar masyarakat menjadi subjek kepariwisataan. Objek studi adalah bentuk dan fungsi sosial rumah adat Bali kuno (Bale Mundhak) yang langka dan widya wisata berbasis ekologi budaya. Bale Mundhak milik Ni Nyoman Remben merupakan tempat melaksanakan ritus keluarga, seperti ritual inisasi, ritual ketuhanan, pernikahan, dan kematian. Keunikan bentuk dan fungsi sosial Bale Mundhak menjadi menarik untuk dikaji dan dijadikan objek wisata. Permasalahannya, bagaimana membangun kepariwisataan dari bawah (Buttom up Tourism), bagaimana memosisikan aspek ekologis Bale Mundhak sebagai elemen ritus dan kultur tanpa harus dieksploitasi, dan bagaimana peran masyarakat lokal sebagai stakeholder yang dapat menikmati manisnya kepariwisataan. Semua itu memerlukan model revitalisasi bentuk dan fungsi Bale Mundhak di Desa Mengesta sebagai wisata budaya dan alam yang berbasis pada konsep wisata desa. Atas dasar itulah artikel ini mengungkapkan salah satu hasil penelitian Strategis Nasional yang mengedepankan konsep ecotourism dalam aktivitas masyarakat.

Kondisi fisik Bale Mundhak milik Ni Nyoman Remben kurang terawat, tetapi sering dikunjungi wisatawan asing usai makan siang di restoran tengah hutan dan menikmati wisata alam dengan bersepeda angin, motor, atau mobil. Tetangga Desa Mengesta-Desa Jatiluwih-sudah ditetapkan sebagai desa wisata alam dan budaya. Publikasi sudah dilakukan, tetapi terdapat ketidaksiapan masyarakat lokal dan komponen pendukung wisata.
Kelemahan itu akan dapat diatasi apabila disusun planning yang komprehensif, baik fisik maupun non-fisik dengan landasan konseptual untuk revitalisasi aset Desa Mengesta sebagai objek wisata alam dan budaya yang berkesinambungan.

Pengemasan model desa wisata rumah adat Bali kuno di Desa Mengesta, Kecamatan Penebel merupakan salah satu upaya pelestarian budaya dan sarana pembentukan karakter generasi muda berbasis budaya. Identifikasi seni budaya dimaksudkan untuk mendeskripsikan bentuk-bentuk kegiatan ritual di rumah adat (Bale Mundhak) yang terkait dengan seni budaya, dan lingkungan sosial. Berdasarkan hasil identifikasi dan deskripsi dapat disusun perancangan model kesenian rakyat kreatif. Pengembangan terhadap wisata rumah adat Bali kuno dimaksudkan untuk pengemasan seni budaya dengan lingkungan sosial dan alam setempat berdasarkan pada konsep-konsep perancangan wisata yang disusun dengan mempertimbangkan ciri khas budaya setempat. Pengemasan dilakukan secara kreatif inovatif dengan metode sharing and sugestion secara dialogis agar masyarakat setempat tidak merasa digurui, ditekan, dan dipasung kreativitasnya. Akan tetapi, rancangan yang telah disusun pun terbuka untuk diubah dan disesuaikan.

Hasil perancangan desain wisata rumah adat Bali kuno akan memperkaya wawasan dan praktik wisata bagi masyarakat Bali khususnya, dan Indonesia pada umumnya. Selain itu, berfungsi sebagai referensi pembelajaran sosial budaya bagi masyarakat. Hasil dokumentasi audio visual model wisata bermanfaat sebagai salah satu sumber dan materi pembelajaran sosial budaya kepariwisataan bagi para pecinta seni dan atau siswa (SD, SMP, dan SMA) maupun mahasiswa dari berbagai disiplin ilmu yang terkait dunia wisata. Atas dasar itu telah dirumuskan permasalahan sebagai berikut: (1) Bagaimana identifikasi fungsi Bale Mundhak sebagai rumah adat Bali di Desa Mengesta, Kecamatan Penebel, Kabupaten Tabanan; (2) Bagaimana identifikasi bentuk-bentuk 
seni budaya setempat yang menyertai fungsi Bale Mundhak sebagai tempat ritus; dan (3) Bagaimana perancangan desain pengalaman turistik Bale Mundhak yang terkait dengan aktivitas kesenian dan masyarakat.

Artikel penelitian ini merupakan bentuk pemecahan masalah strategis yang berskala nasional, sehingga memiliki nilai guna sebagai berikut: (1) Dapat dijadikan pijakan oleh masyarakat untuk mengembangkan kreasi yang inovatif sesuai situasi zaman. Kreasiinovasi masyarakat akan berdampak pada peningkatakan kesejahteraan sosial, sehingga eksistensi rumah adat Bali kuno, seperti bentuk dan fungsi Bale Mundhak memperoleh daya penguat. (2) Masyarakat umum memperoleh informasi dan pengalaman terkait dengan pengakuan terhadap eksistensi kekayaan budaya Nusantara. Hal ini, memberi kontribusi terhadap ketahanan budaya lokal yang berdampak pada stabilitas dan integrasi nasional. (3) Bagi pemerintah Tabanan khususnya, Bali dan Indonesia secara umum, penguatan terhadap eksistensi budaya lokal dapat mendukung program industri kreatif yang telah dicanangkan sejak tahun 2009, dan hasilnya diharapkan dapat menambah Pendapatan Asli Daerah (PAD). (4) Stakeholders dapat merangsang dinamika ekonomi masyarakat dan secara kultur ikut membangun konstruksi sosial budaya yang kokoh.

Suatu pola strategis dalam penguatan ecotourism dapat didasari dari sebuah motivasi perjalanan berwisata. Namun, kegiatan yang sering bersentuhan dengan hal-hal terpenting dunia wisata akan selalu melibatkan faktor pendorong dan penarik kuat bagi orang yang akan melakukannya. Faktor ini dapat diasumsikan dari sebuah motivasi berwisata. Secara umum dalam pendekatan wisata, motivasi merupakan hal yang sangat mendasar dalam studi tentang wisatawan dan pariwisata karena motivasi merupakan spirit dari proses perjalanan wisata.

Menurut Gede Pitana dan Putu Gayatri motivasi utama wisatawan untuk mendapatkan sebuah authentic experience atau pengalaman otentik (Pitana dan Gayatri,
2005: 58). Oleh sebab, itu dengan acuan McIntosh dan Murphy, dijelaskan oleh Pitana dan Gayatri (2005: 59) bahwa motivasi dapat dikelompokkan ke dalam 4 (empat) kelompok pengunjung. Ecotourism itu sendiri telah menjadi landasan konseptual dari sebuah kegiatan yang melibatkan masyarakat di lingkungan objek wisata. Pola ecotourism sering dimaknai sebagai produk pariwisata alternatif yang mempunyai tujuan seiring dengan tujuan pembangunan pariwisata berkelanjutan. Secara alternatif pola yang dikembangkan dalam ecotourism memberi manfaat yang layak secara ekonomi dan adil secara etika. Selain itu secara sosial pengembangan basis ecotourism memberikan manfaat bagi masyarakat untuk ikut bertanggungjawab bagi kelangsungan hidup lingkungan sekitarnya dan bagi generasi muda (Watson dan Kopachevsky dalam Pitana, 2005). Pada level implementasi ecotourism atau ekowisata meningkatkan partisipasi aktif masyarakat berdasarkan konsep yang dimaknai mereka dalam pemanfaatan dan pengelolaan aset kultur, sehingga memberikan nilai baru dalam bentuk aset ekonomi. Dengan demikian desain pengalaman turistik yang menjadi implikasi ekowisata paling tidak mengacu pada hal-hal sebagai berikut: (1) Pengalaman turistik sebagai edukasi dan apresiasi, (2) Pengalalaman turistik sebagai penguatan karakter, (3) Pengalaman turistik sebagai penghormatan alam dan lingkungan, dan (4) Pengalaman turistik sebagai kontribusi kultur.

Penelitian ini menggunakan data kualitatif dan menerapkan metode deskriptif analitis. Pendeskripsian secara analitis untuk mengetahui kekuatan, kelemahan, peluang, dan ancaman terhadap potensi rumah adat Bali kuno di Desa Mengesta, Kecamatan Penebel. Data diperoleh dari observasi dan wawancara. Penelitian ini menerapkan pendekatan kaji tindak (actionresearch) dan membutuhkan tindakan kreatif inovatif. Penelitian ini hendak mengangkat potensi sosial, seni, budaya, dan alam agar dapat meningkatkan kesejahteraan masyarakat, ketahanan budaya bangsa, dan stabilitas nasional. 
Langkah selanjutnya adalah proses reproduksi seni budaya yang terkait dengan ritus tertentu Bale Mundhak. Proses ini menggunakan pendekatan sharing and sugestion secara dialogis dengan mengacu pada rancangan pengemasan. Pendekatan ini dimaksudkan agar kelompok-kelompok masyarakat sosial budaya tidak merasa digurui, ditekan, dan dipasung kreativitasnya. Oleh sebab itu, rancangan yang telah disusun terbuka untuk disesuaikan dan diubah agar lebih sempurna.

Penelitian ini menggunakan data kualitatif yang diperoleh dari: (1) sumber tertulis, (2) dokumen, dan (3) sumber lisan diperoleh dari masyarakat, perangkat desa, tokoh masyarakat, budayawan, kelompok seni budaya, kelompok tani, dan kelompok pengrajian.

Pengumpulan data dalam penelitian ini dilakukan dengan teknik wawancara, studi pustaka, observasi, dokumentasi, dan Focus Group Discussion (FGD). Untuk menjaga keabsahan data digunakan teknik triangulasi sumber, triangulasi teori, triangulasi metode, Focus group discussion, review informant, dan peerdebriefing.

\section{PEMBAHASAN}

Artikel ini berupaya mempresentasikan sebuah rancangan pemberdayaan fungsi Bale Mundhak sebagai sebuah aset kultur rumah adat Bali kuno di Desa Mengesta, Kecamatan Penebel, Kabupaten Tabanan. Paparan artikel ini merupakan implementasi yang dapat dijabarkan dari luaran Hibah Strategis Nasional tahun 2013 dengan fokus perancangan desain pengalaman turistik yang berpijak dari pola rural space heritage atau dalam bahasa bangunan sering diterjemahkan sebagai warisan ruang desa. Beberapa hal yang dapat diuraikan dalam artikel ini meliputi faktor-faktor pendorong dan penarik sebagai ukuran pola alternatif dalam ecotourism.

\section{Faktor Pendorong dan Penarik}

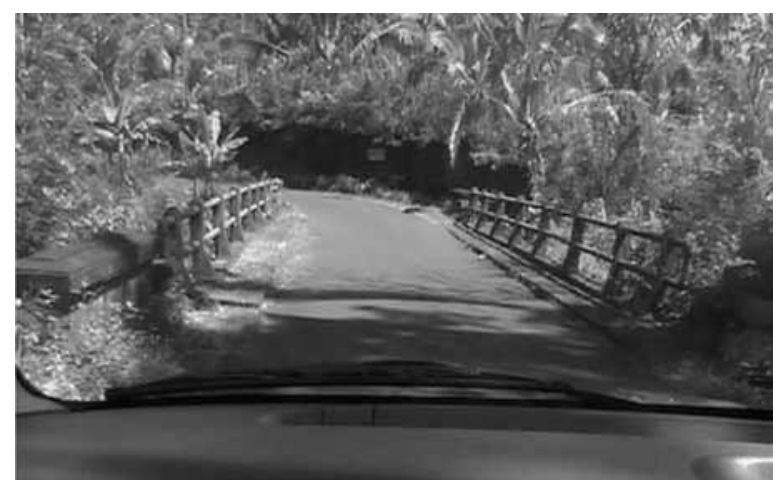

Gambar 1.

Jembatan penghubung antara penebel dan Desa Mangesta terletak di ujung selatan Desa Mangesta. Foto: koleksi PKPBN ISI Surakarta 2013.

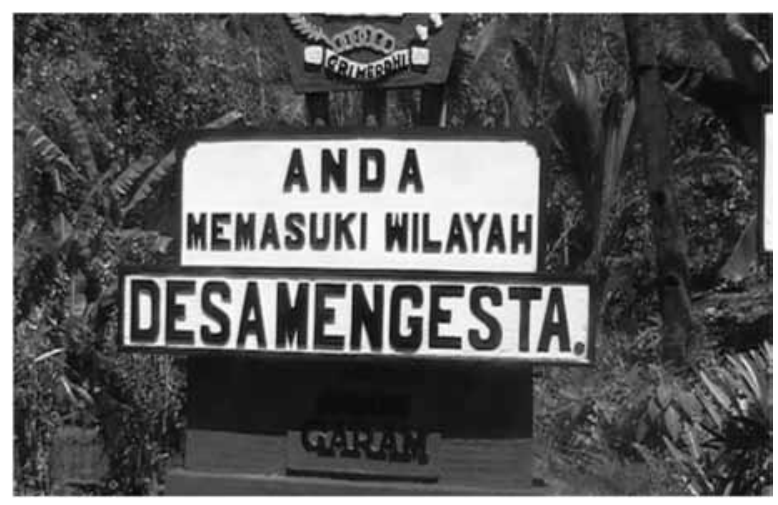

Gambar 2.

Perbatasan bagian Selatan terletak di ujung Selatan Desa Mangesta. Foto: koleksi PKPBN ISI Surakarta 2013.

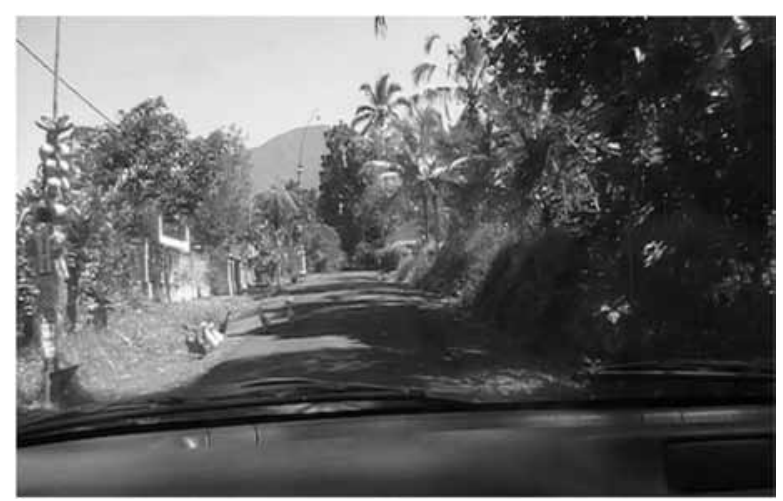

Gambar 3.

Jalan menuju di Dusun Mangesta, Foto: koleksi PKPBN ISI Surakarta 2013. 


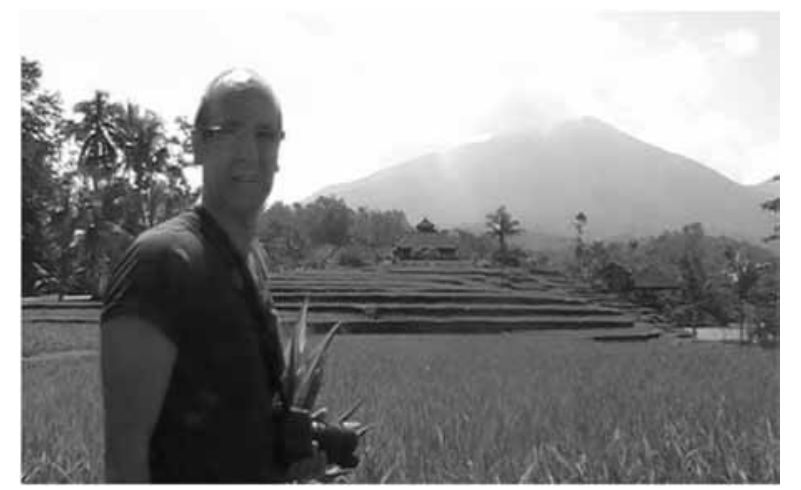

Gambar 4.

Pemandangan alam di sekitar Dusun Mangesta terletak di ujung Utara Dusun Mangesta. Foto: koleksi PKPBN ISI Surakarta 2013.

Selain itu, suatu motivasi perjalanan berwisata pemberian batasan tentang pariwisata sebagaimana halnya dengan berbagai subjek lain memang sering tidak dapat menghasilkan satu batasan yang memuaskan untuk berbagai kepentingan. Namun kegiatan yang acapkali bersentuhan dengan hal-hal terpenting dunia wisata akan selalu melibatkan faktor pendorong dan penarik kuat bagi orang yang akan melakukannya. Faktor ini dapat diasumsikan dari sebuah motivasi berwisata. Secara umum dalam pendekatan wisata, motivasi merupakan hal yang sangat mendasar dalam studi tentang wisatawan dan pariwisata karena motivasi merupakan spirit dari proses perjalanan wisata.

Menurut Gede Pitana dan Putu Gayatri motivasi utama wisatawan untuk mendapatkan sebuah authentic experience atau pengalaman otentik (Pitana dan Gayatri, 2005: 58). Unsur perjalanan dengan motivasi besar tampak sekali mendominasi keinginankeinginan yang menjadi wilayah destinasi wisatawan. Menurut asumsi ini, maka makna perjalanan menempati nilai tertinggi dalam motivasi berwisata. Oleh sebab itu, McIntosh dan Murphy dijelaskan oleh Pitana dan Gayatri (2005: 59) bahwa motivasi dapat dikelompokkan ke dalam 4 (empat) kelompok sebagai berikut: (1) Physical or physiological motivation (motivasi yang bersifat fisik atau fisiologis), antara lain untuk relaksasi, kesehatan, kenyamanan berpartisipasi dalam olah raga dan bersantai. (2) Cultural motivation (motivasi budaya) yaitu keinginan untuk mengetahui budaya, adat istiadat, tradisi dan kesenian daerah lain. Termasuk dalam hal ini ketertarikan pada objek peninggalan budaya (monumen bersejarah). (3) Social motivation atau interpersonal motivation (motivasi yang bersifat sosial), seperti mengunjungi teman dan keluarga (VFR atau visiting friends and relatives), menemui mitra kerja, melakukan hal-hal yang dianggap mendatangkan gengsi (nilai prestise), melakukan ziarah, pelarian dari situasi-situasi yang membosankan, dan seterusnya. (4) Fantasy motivation (motivasi karena fantasi), yaitu adanya fantasi bahwa di daerah lain seseorang akan dapat lepas dari rutinitas keseharian yang menjemukan. Hal ini disebut pula sebagai status and prestige motivation.

\section{Rancangan Karakter Jalur Ecotourism Bale Mundhak}
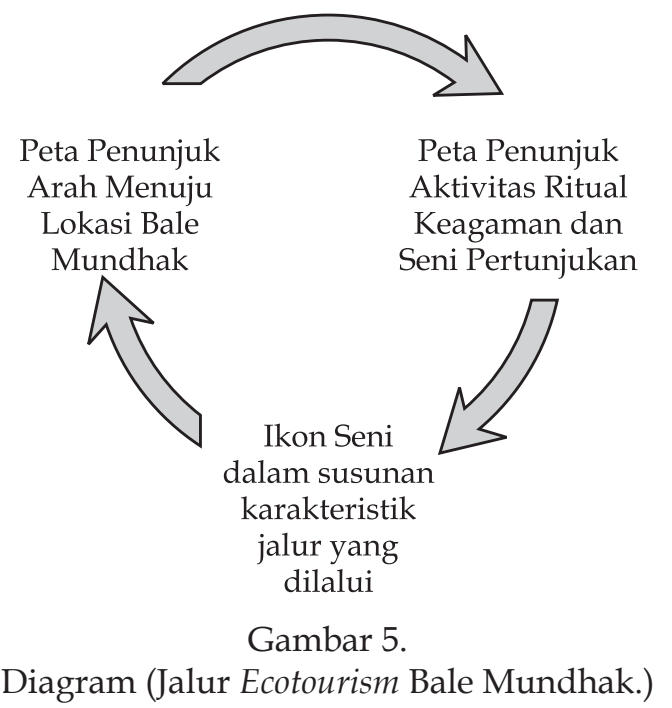

Selain itu, dipengaruhi pula oleh faktor internal dan eksternal. Faktor internal adalah berasal dari wisatawan itu sendiri, sedangkan faktor eksternal lebih banyak diperoleh dari pengaruh atau tekanan keluarga, dan situasi kerja yang terinternalisasi (Pitana dan Gayatri, 2005: 60).

Jika memperhatikan nilai motivasi begitu penting dalam menarik dan mendorong seseorang atau sekelompok orang berwisata, kiranya pada proses penciptaan produk kreatif 
pemanfaatan rural space dengan pendekatan wisata ini perlu mengelaborasikan maknamakna motivasi wisatawan yang diacu dari berbagai pernyataan di atas. Beberapa hal sudah mulai dapat dipertimbangkan, antara lain sifat-sifat kejiwaan atau situasi psikologis pelancong harus dipertimbangkan terlebih dahulu dalam menjembatani nilai motivasi di atas.

Sudah barang tentu wayang sebagai sebuah produk kreatif akan diujikan terlebih dahulu melalui keseimbangan situasi psikologis dengan motivasi fisiologis kategori wisatawan minat khusus. Kepentingan yang lebih rinci dapat dielaborasikan dalam implementasi akan kebutuhan relaksasi dalam menyaksikan desain pengalaman turistik itu sendiri ataukah sebaliknya tidak ada motivasi bernilai kebutuhan relaksasi. Hal disebabkan, bahwa kedudukan karakter jalur sebagai sebuah produk kreatif sejajar dengan tingkat berpartisipasi olahraga atau bersantai yang terwadahi dari motivasi kategori wisatawan dalam menikmatinya.

Terkait langsung dengan hal ini motivasi kultural adalah bentuk pendorong dan penarik yang paling dominan dalam penikmatan produk kreatif karakter jalur. Hal ini didasarkan pada alasan bahwa pemahaman desain pengalaman sebagai sebuah produk budaya lebih menyentuh aspek emosional dalam perkembangan psikologis kategori wisatawan. Anggapan terhadap makna bentuk kemasan aktivitas di dalam desain pengalaman sebagai teks turisme minat khusus akan dipengaruhi oleh sejumlah perasaan ketertarikan seseorang anak akan adat istiadat, tradisi, dan peninggalan monumen kesejarahan. Hanya saja dikarenakan muatan aspek kepuasan pengalaman harus terwadahi di dalam nilai kemasan produk kreatif karakter jalur, maka arti teks budaya ini harus dielaborasikan dengan wilayah atraksi wisata yang disesuaikan dengan perkembangan emosional dan psikologis wisatawan.

Makna motivasi sebagai pendorong dan penarik yang bersifat antar-personal dalam situasi psikologis sekelompok wisatawan minat khusus, maka pemenuhan nilai kemasannya juga turut mempertimbangkan terwadahinya pelepasan-pelepasan situasi membosankan yang didapatkan sekelompok pelancong di luar aktivitas ini. Dari sinilah sebuah format akan diujikan dari caracara kemas sebagai pertimbangan mengeliminasikan nilai pengalaman estetis sebagai sesuatu yang tidak 'memberatkan'. Situasi pendorong yang sejajar dapat diwadahinya nilai motivasi sekelompok wisatawan untuk menghindari dunia yang menjemukan ketika mendapatkan pengalaman otentik di wilayah penyajian cara kemas karakter jalur dan aktivitas kultur.

Atas dasar itu, maka faktor pendorong dan penarik dan kaitannya dengan pertimbangan cara kemas yang ditawarkan sebagai suatu produk kreatif di dalam Bale Mundhak akan menentukan berbagai pertimbangan cara kemas yang dielaborasikan dari sebuah pendekatan wisata. Hal ini sebenarnya adalah sebuah cara lain dari mempertimbangkan aspek ecotourism dengan modifikasi-modifikasi tertentu yang mewadahi segala bentuk motivasi di luar rutinitas studinya. Pada anggapan ini, maka produk kreatif karakter jalur dengan tinjauan aspek ajaran moral akan dimaknai dalam pertimbangkan cara kemas itu sendiri. Seseorang wisatawan atau sekelompok wisatawan akan bersedia hadir memenuhi area Bale Mundhak ini dapat diandaikan seperti menempuh sebuah perjalanan wisata. Sebagai makna perjalanan wisata, maka diperlukan memetakan sebuah motivasi sebagaimana disebutkan terdahulu ke dalam kombinasi-kombinasi motivasi yang telah dikelola dalam sebuah format khusus. Sudut pandang pariwisata dalam konsep Richardson dan Fluker seringkali menyebutkannya sebagai motivasi spesifik atau wisata minat khusus atau special interest tourism atau juga disebut new tourism (Soetarno, 2004: 71). Sesuatu harus segera dieksplanasi kembali ketika kategori wisata minat khusus ini dikaitkan dengan kategori partisipan terpilih seperti dalam sasaran produk kreatif dalam aktivitas lokasi ini. 
Sangat jelas bahwa minat khusus yang dimaksud dengan kategori pelancong minta khusus seperti pada penelitian ini memerlukan pemetaan pula untuk menjembatani nilai motivasi dan keinginan yang ingin dicapai seusai menyaksikan produk kreatif yang terjadi sepanjang karakteri jalur Bale Mundhak dengan penekanan aspek ecotourism. Kenyataan menunjukkan bahwa dalam pendekatan wisata diketahui nilai gaze atau kenikmatan lebih diutamakan daripada nilai pengalaman. Jadi pertimbangan memilih format dan cara kemas akan menduduki proporsi utama dalam wilayah ini. Secara singkat menyaksikan produk karakter jalur Bale Mundhak adalah perjalanan wisata itu sendiri, dan bukan yang lain-lain.

\section{Produk Kreatif Cara Kemas Wisata Rumah Adat Bale Mundhak}

Pertama-tama akan dijelaskan terlebih dahulu berbagai pendekatan wisata yang seringkali digunakan dalam mengemas produk-produk seni pertunjukan yang melekat dalam fungsi bangunan Bale Mundhak. Secara antropologis, R.M. Soedarsono selalu menguraikan pendekatan seni wisata dari sudut pandang gaya penampilan. Mengacu pada teori antropologi estetik Jaques Maquet, maka dinyatakan bahwa kemasan seni untuk wisata sering dikatakan sebagai art by metamorphosis atau art of acculturation atau pseudo-traditional art (R.M. Soedarsono, 2001). Pada sebuah Seminar tentang seni pertunjukan dan pariwisata, pandangan Soedarsono memunculkan sebuah ciri-ciri format sebagai hasil penelitiannya yaitu (1) tiruan aslinya, (2) dikemas singkat atau padat, (3) dikesampingkan nilai-nilai sakral, magis, dan simbolisnya, (4) penuh variasi, dan (5) murah harganya (R.M. Soedarsono, 2001: 3).

Beberapa pengkajiannya Soedarsono juga selalu menggunakan model diagram Wimsatt sebagai sistem kendali persinggungan nilai ekonomi dan nilai estetis pada seni wisata.

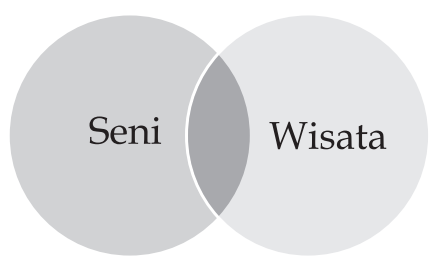

Gambar 6.

Diagram Sistem Kendali Persinggungan Nilai

Ekonomi dan Nilai Estetis pada Seni Wisata

Menurut diagram ini nilai seni dan ekonomi pada pariwisata harus seimbang. Jika proporsi kedua-duanya tidak seimbang, maka akan dianggap sebagai tidak ideal. Sebuah kondisi realitas pada persinggungan kedua aspek nilai di atas pernah mendapat perhatian dalam penelitian R.M. Pramutomo telah menyoroti dari sudut pandang budaya dan dipublikasikan dalam sebuah buku tahun 2007 bersama-sama Sri Rochana Widyastutieningrum (Sri Rochana W dan R.M. Pramutomo, 2007). Walaupun penekanan kajian ini pada nilai kritis terhadap kemungkinan dampak yang diakibatkan oleh nilai-nilai industri, tetapi sesuatu yang bersifat cara kemas haruslah bertimbang pada perspektif pemikiran masyarakat era-industri.

Dinyatakan antara lain bahwa secara periodik industri pariwisata telah memasuki wilayah kehidupan lokal. Hal ini tidak dapat dipungkiri. Akibat diterobosnya wilayah kehidupan budaya tersebut sangat dimungkinkan munculnya bentuk wisata budaya dalam formatnya yang khas. Tiada terkecuali bentuk-bentuk seni pertunjukan tradisional yang telah mengalami perubahan maupun pertambahan fungsi, yaitu sebagai tontonan wisatawan.

Mengacu pada pernyataan Sardono W Kusumo tentang prediksi terhadap trend wisata budaya di tahun 1996, tetapi beberapa butir pernyataannya lebih merupakan antisipasinya sehubungan dengan akan dibukanya sebuah Bandara Internasional.Akan tetapi, secara komprehensif cukup dijadikan alasan pemikiran bagi pemerhati kesenian wisata di tanah air. Salah satu ungkapan yang muncul di antaranya sifat-sifat given by nature yang dalam istilah Sardono sepertinya belum disadari oleh para pelaku seni pertunjukan 
wisata sebagai pengalaman cultural exchange (dalam makna yang sesungguhnya), yang diperoleh melalui kontak dengan wisatawan (asing). Kalau pun akan mengurai satu demi satu setiap permasalahan yang ada, maka semakin berada dalam lingkaran masalah. Atau mungkin juga terlalu berpikir berat ketika kata-kata 'industri' itu langsung menempel di depan kata pariwisata.

Satu hal yang mungkin hanya sedikit diketahui bahwa pariwisata mempunyai segalanya. Ia memiliki policy terhadap wilayah kehidupan seni tradisi, sementara para pelaku seni pertunjukan wisata tidak memilikinya. Bila benar demikian, apakah sejak kebijaksanaan industri pariwisata diterjemahkan sebagai sumber devisa negara non-migas, maka sejak itu pula pola kebijaksanaan pariwisata juga telah menjadi pola kebudayaan industrial (supaya tidak terburu-buru menyebut seni pertunjukan wisata sebagai seni masyarakat industri)? Pertanyaan ini barangkali terlalu riskan untuk dilontarkan.

Suatu hal yang sangat wajar sebagai acuan dari sebuah kenyataan historis bahwa negara industri (yang sedang dibayangkan) dalam konsepsi kebudayaan industri negara Indonesia di masa datang masih sangat jauh dari bayangan yang ada sekarang. Seperti halnya bila membandingkan dengan suatu fase perkembangan masyarakat, tempat kategori masyarakat yang sedang menuju fase modern society, sudah barang tentu akan terlebih dahulu melewati fase transisional modernized society. Asumsinya bahwa sesuatu yang sedang dibayangkan tadi pada gilirannya akan menjadi sebuah perumusan dari fase industrialized society (bukan berarti sama dengan industrial society). Hal ini disebabkan oleh fakta historis bahwa mentalitas kebudayaan industri masyarakat Indonesia belum seluruhnya mantap. Masih serba tanggung, di mana nilai-nilai kebudayaan agraris masih melekat, sementara datangnya nilai baru (mental spirit) kebudayaan industri juga belum mapan, sebuah ciri dari perbenturan mentalitas masyarakat sedang berkembang.
Walaupun demikian, industrialisasi yang telah mengemuka sebagai isu sentral di setiap Pelita (di masa Orde Baru) telah turut memberi makna baru bagi dunia pariwisata, yaitu industri pariwisata. Jika benar begitu, maka setiap persoalan aktual dalam industri pariwisata (seharusnya) merupakan persoalan kebudayaan di Indonesia, yaitu kebudayaan industri. Dengan kata lain, apakah benar jika pola perkembangan pariwisata itu paralel dengan kebijakan pariwisata, maka akhirnya nanti kebijaksanaan itu akan mengikuti arus industrialisasi?

Kiranya pada keadaan ini Ignas Kleden sebenarnya telah mencoba menguraikan fenomena terhadap basis industri yang (seharusnya) dibayangkan, yaitu Rakyat Indonesia hanya mungkin bekerja atas landasan standarisasi (Kleden, 1987). Produksi massa akan mengandaikan konsumsi massa. Standarisasi produksi akan mendukung standarisasi selera dan gaya hidup. Akhir dari penyeragaman gaya hidup adalah homogenisasi kebudayaan. Pada kondisi demikian sebenarnya pola pengembangan pariwisata telah mengikuti arus kebudayaan massa. Kenyataan historis munculnya wisata budaya (termasuk seni pertunjukan wisata) juga sudah menampakkan gejala yang sama seperti dalam sebutan Kleden. Berbagai pandangan seputar pro dan kontra terhadap kehadiran seni pertunjukan wisata sampai dengan hari ini masih menyiratkan permasalahan industrialisasi. Di sinilah letak perspektif pemikiran itu tidak semata-mata melulu mengacu pada urgensi ekonomis, melainkan juga mempertimbangkan urgensi strategis.

Sampai di sini harus diakui bahwa hampir setiap pemikiran yang mencoba bergulat dengan persoalan wisata budaya akan selalu menghadapi sebuah kesulitan tetap, yaitu pilihan untuk menjadikan pemikiran terhadap domain wisata yang berorientasi kepada nilai ekonomis, atau yang dapat memberikan kontribusi terhadap domain budaya, dengan berorientasi kepada nilai luhur kemanusiaan umum (termasuk makna pengalaman cultural 
exchange). Pada arah pemikiran wisata budaya, kiranya tiada jauh berbeda dengan pilihan di atas. Di satu sisi kehadiran seni wisata telah dihadapkan pada pilihanuntukmenjadikannya berada di tengah jalur industri karena produk keseniannya telah diberi nilai ekonomis. Sementara itu di sisi yang lain pilihan untuk mempertimbangkan nilai estetis menyiratkan ekstensinya ke dalam pertanggung jawaban moral. Salah satu risiko yang sering muncul, bila dikarenakan suatu masalah kedua wilayah, baik seni dan ekonomi dapat saling terobos sebuah ancaman dari mentalitas serba semu.

Pada asumsi yang seperti ini kebutuhan format dan cara kemas dalam arti produk kreatif karakter jalur dapat dimulai dari sebuah reserach action melalui pemahaman memberlakukan gaya penampilan seni dalam bentuknya seperti sebuah perjalanan wisata. Gagasan menampilkan sebuah model atau format belum pernah mendapat perhatian khusus dalam kategori pelancong. Apalagi muatan ajaran nilai moralitas yang tertanam dalam sebuah pertunjukan di dalam bangunan rumah adat belum pernah direaktualisasi dalam sebuah pertimbangan cara kemas. Salah satu urgensi penuangan model reaktualisasi nilai ajaran moral melalui produk kreatif sangat memungkinkan mendapatkan pemahamannya sebagai sebuah produk perjalanan wisata.

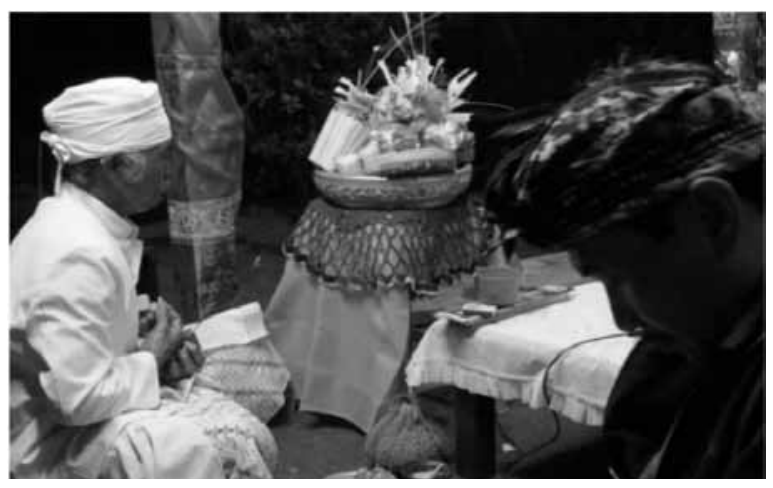

Gambar 7:

Mangku I Ketut Sandra di Bale Mundhak Ni Nyoman Remben sedang berdoa menjelang acara megeguritan. Foto: PKPBN ISI Surakarta 2013.

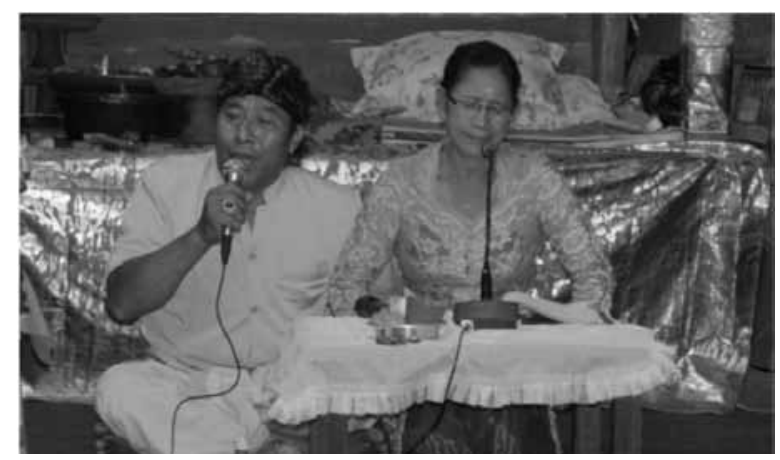

Gambar 8:

I Nyoman Suparta dan Ni Nyoman Wati di Bale Mundhak Ni Nyoman Remben sedang megeguritan. Foto: PKPBN ISI Surakarta 2013.

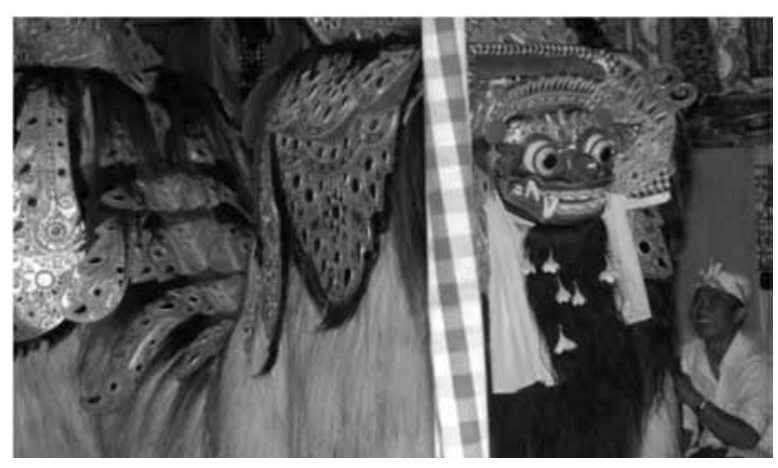

Gambar 9:

Barong Dusun Mangesta dalam Dramatari Calonarang di Pura Pusah Dusun Mangesta dalam Upacara Odalan. Foto: PKPBN ISI Surakarta 2013.

Akan tetapi, sebuah pernyataan lain yang langsung memberi fokus perhatian pada jenis penampilan seni wayang dipaparkan oleh Soetarno dalam sebuah seminar yang sama di tahun 2001. Dinyatakan bahwa salah satu dampak yang sering dianggap negatif dalam model aktivitas wisata adalah proses komoditas (Soetarno, 2001: 5). Mengacu pada pendapat ini, maka proses komoditas yang dimaksud dalam aktivita wisata benar-benar dilihat dari sudut ekonomi. Barangkali benar jika acuan ini dikaitkan dengan dampak ekonomi yang melekat langsung pada aktivitas wisata. Jalur-jalur ekonomi yang telah disebutkan oleh Soetarno dinyatakan antara lain sebagai berikut: (1) Jalur akomodasi, (2) Jalur atraksi/kreasi, (3) Jalur konsumsi, (4) Jalur informasi, dan (5) Jalur transportasi (Soetarno, 2001: 4). 
Pada arti tersedianya jalur-jalur di atas, maka wisatawan yang datang di daerah tertentu misalnya akan memerlukan akomodasi yang memadai sebagaimana tinggal di daerah asalnya. Dengan demikian tentu akan melahirkan kompleksitas interaksi yang sangat intensif. Jalur atraksi/kreasi diandaikan dari para wisatawan juga memerlukan hiburan, cinderamata atau souvenir, pengalaman emosi, bahkan pengalaman tubuh yang diperoleh di daerah tujuan. Pada perkataan lain, segala sesuatu yang berupa produk locus adalah produk wisata. Aspek seni kerajinan akan turut terpengaruh dengan perkembangan kedatangan wisatawan di sebuah locus. Selain itu informasi mengenai keadaan objek atau locus menjadi keterangan yang sangat penting bagi calon wisatawan. Pada saat yang sama di samping akomodasi mengisyaratkan kemudahan bagi wisatawan, maka kebutuhan konsumsi juga menjadi bagian penting dalam jalur wisata ini. Keinginan merasakan cita rasa kuliner khas di sebuah locus tertentu adalah salah satu ciri utama wisatawan. Rangkaian utama pada tersedianya jalur ekonomi pada sebuah aktivitas wisata adalah transportasi. Standar yang digunakan pada sebuah biro perjalanan wisata akan menentukan kepuasan wisatawan dalam berkunjung ke sebuah objek atau locus.

Paparan di atas adalah sebuah aktivitas jalur yang lazim diselenggarakan dalam sebuah kegiatan wisata. Kembali pada fokus penciptaan produk kreatif desain pengalaman turistik yang cara kemasannya diandaikan sebagai sebuah aktivitas perjalanan wisata, maka di bawah ini akan disajikan sebuah diagram yang diperbandingkan dari konsep jalur aktivitas.

\section{akomodasi}

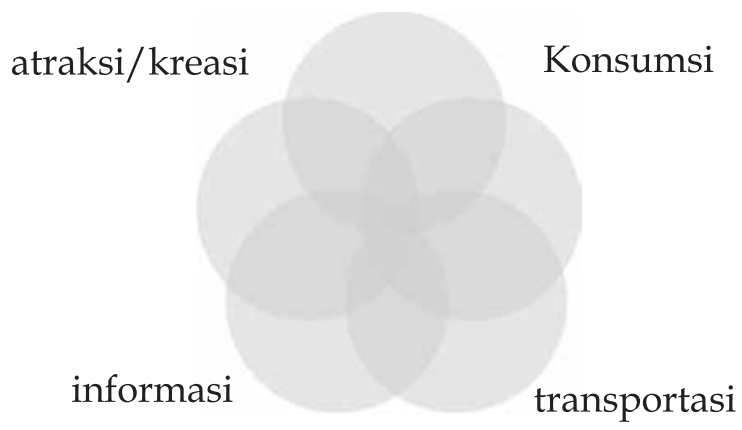

\section{SIMPULAN}

Paparan artikel ini sebenarnya mencoba menguraikan aspekecotourism sebagai bentuk cara kemas desain pengalaman turistik yang ingin ditawarkan dalam sebuah aktivitas masyarakat di seputar Bale Mundhak. Capaian yang tertuang dalam artikel ini, pada tahun pertama telah disusun sebuah rancangan fungsi sosial Bale Mundhak sebagai rumah adat Bali kuno di Desa Mengesta, Kecamatan Penebel, Kabupaten Tabanan. Implikasi utama dari capaian tahun pertama masa riset merupakan tersusunnya rancangan model wisata rumah adat Bali kuno di Desa Mengesta, Kecamatan Penebel, Kabupaten Tabanan, Bali. Hal ini sebenarnya menjadi pijakan dari sebuah desain pengalaman melalui tersusunnya interelasi antara rumah adat Bali kuno, ritus keagamaan, dan seni (tari dan musik gamelan Bali) secara indigeneus. Produk ini pada gilirannya diharapkan akan menghasilkan indikator pokok dalam menempatkan fungsi sosial Desa Mengesta sebagai mata rantai lintasan wisata. Atas dasar itu artikel ini telah sampai kepada pendapat bahwa perancangan desain pengalaman turistik dalam basis ecotourism Rumah Adat Bale Mundhak berpotensi besar untuk dilalui wisatawan menuju wisata alam dan budaya di Kecamatan Penebel, Kabupaten Tabanan, Bali.

\section{DAFTAR PUSTAKA}

Ardika, I Wayan. "Pengelolaan Pusaka Budaya sebagai Obyek dan Tarik Pariwisata Bali", makalah disampaikan pada Seminar Bali Bangkit Departemen Pendidikan dan Pariwisata. Denpasar, 20 Agustus 2006.

Bandem, I Made. "Peranan Seni dan Budaya sebagai Komoditas dalam Pengembangan Industri Pariwisata". Seminar Nasional Pariwisata BudayaProgram Magister (S2) Kajian Budaya Universitas Udayana Denpasar, 1098. 
Murtana, I Nyoman. "Pemberdayaan Masyarakat Lokal dalam Aktivitas Pariwisata Budaya Bali". Dalam Jurnal Dewaruci ISI Surakarta, volume 5, no.2 Desember 2008.

Pichard, Michel. Bali: Pariwista Budaya dan Budaya Parwista. Terjmahan Jean Couteau dan Warih Wisatsana. Jakarta: Kepustakaan Populer, 2006

Pitana, Gede, dan Gayatri Putu. Sosiologi Pariwisata, Yogyakarta: Kanisius, 2005
Soetarno, "Seni Pertunjukan Wayang Kulit untuk Wisatawan", makalah Seminar Nasional ISI Surakarta, 2004.

Sri Rochana dan R.M. Pramutomo, Penulisan Kritik Tari, Surakarta: ISI Solo Press, 2007

Watson dan Kopachevsky. "Interpretation of Tourism as Commodity" dalam Yorgos Apostolopoulos, at. All. Eds., The Sociology of Tourism: Theoritical and Empirical Imvestigations. London: Routledge, 2002. 